\title{
Post-Operative Use of Dopamine Agonist in Management of Remaining Nonfunctioning Pituitary Adenoma
}

\author{
AHMED ADEL AYAD, M.D. \\ The Department of Neurosurgery, Faculty of Medicine, Al Azhar University
}

\begin{abstract}
Background: Complete tumor elimination via transsphenoidal surgical operation is frequently hard for large nonfunctioning pituitary adenomas (NFPAs). A confirmed medical treating might be beneficial for their managing.

Aim of Study: To investigate the effectiveness of dopamine agonist medication in decreasing or avoiding the re-growing of NFPA after ward surgical operation.

Patients and Methods: This was a prospective, randomized, clinical trial done in Al-Azhar University Hospitals was conducted on 20 patients experienced primary transsphenoidal surgical operation for pituitary adenoma management, the study was carried out through a period of 12 months from March 2020 to March 2021.

Results: Tumour reduction rate of remaining cancer mass was significantly higher in medically-treated group, while tumour growing rate of remaining tumour mass was significantly elevated in controls.

Conclusion: Cabergoline (dopamine agonist was an effective medication for the treatment of remaining NFPA, and its usage was accompanying with an elevated tumour shrinkagerates.
\end{abstract}

Key Words: Dopamine Agonists (DA) - Non-Functioning Pituitary Adenoma (NFPA).

\section{Introduction}

NFPAS are between the commonest tumours of the sellar area and are characterised by the nonattendance of clinical or bio-chemical proof of tumour-connected hormone rise [1].

These adenomas are normally big at diagnosing, and signs secondary to mass influences are mutual; those involve complications, visible disorders, and hypopituitarism [2-4]. Most adenomas are capable of synthesize gonadotropins but don't secrete them. [2].

Correspondence to: Dr. Ahmed Adel Ayad, The Department of Neurosurgery, Faculty of Medicine, Al Azhar University
Transsphenoidal operative resections are the 1 st-line treatment for NFPA. But, entire elimination of extremely big tumours may be hard, and those adenomas give an elevated rate of remaining tumour [3]. In those remaining tumours, radio-therapy is a powerful treatment option, with $>90 \%$ tumour controlling over 10-yrs [4]. But, this elevated efficacy is balanced by an elevated occurrence of complications like hypo-pituitarism, cognitive impairment, and danger of strokes [5].

Stereotactic mode is taken into consideration to be more-safe, however the occurrence of hypopituitarism was $72 \%$ over 10 -yrs, identical to that of traditional radio-therapy. For those causes, radiotherapy isn't completely endorsed for the treating the remaining NFPA [6].

Alternative option is medical observation; however, the occurrence of relapse is extremely elevated (67.9\% over $15-\mathrm{yrs})$, and an increased standardized death ratio of 1.65 was described [2,7].

NFPA comprises the commonest shape of pituitary macro-adenomas that needoperative interventions, but they stay the only pituitary tumour subtype for which no medications are powerful. This contrasts with powerful medications existing for the management of hormone-secreting pituitary tumours [8].

The majority of NFPAs express dopamine receptors, mainly dopamine receptors-2 (D2R). Consequently, DA reduces gonadotropin secretions and constrain thymidine combination in vitro, giving a possible treatment goal for NFPA [9]

But, dopaminergic bonding locations in addition to D2R mRNA isoforms are lesser amount in NFPA in comparison to in prolactinomas, possibly in accordance to the modest rate of tumour reductionaccomplished by DAs [10]. Small reports suggested 
that DA might retard NFPA growing, [11,12,13] however to date, this possible treatment modality hasn't been widely experienced [14]

The present study aimed to investigate the effectiveness of dopamine agonist medication in decreasing or avoiding the re-growing of nonfunctioning pituitary adenoma NFPA after ward surgical operation.

\section{Material and Methods}

This was a prospective, randomized, clinical trial done in Al-Azhar University Hospitals was conducted on 20 patients experienced primary transsphenoidal surgical operation for pituitary adenoma management, the study was carried out through a period of 6 months from October 2020 to May 2021.

Eligible adults ( $>18$ years of age) who have a remaining tumour masses detected by MRI 6-mths (+/-1 mo) after ward operation. Exclusion criteria involved silent corticotroph and silent somatotroph tumours, and preceding history of radiotherapy.

Informed written agreement was attained from each case to be involved in this work.

The NFPA diagnosing was founded in the subsequent criteria: (1) Detections of a pituitary tumourvia MRI, with or not local tumour symptoms including headaches and visible acuity/field defect; (2) Non attendance of the medical features of hyper-secretion of frontal pituitary hormone; (3) Attendance of ordinary or small circulating growing hormones $(\mathrm{GH})$, insulin-like growing factors 1 (IGF-1), thyroid-stimulation hormones (TSH), thyroid hormones, adrenocorticotropic hormones (ACTH), or 24-hour urinary cortisol level; and (4) Post-surgical histo-pathologic examinations showing pituitary adenoma. Cases with increased prolactin (PRL; max 50ng/dL) with no medical symptoms of hyper-prolactinemia had been involved. Immuno-histo-chemistry (IHC) for frontal pituitary hormones was achieved in all specimen tumours.

Contributors had been randomized then grouped to the clinical-treatment group (cabergoline) or the controls (medical observations) in a 1:1 ratio. We employed a simple randomizing technique in line with the cases' time of arrival.

a- Medically-treated group: In an open-label way, cabergoline was started at $0.5 \mathrm{mg} 3$ doses every week up to every day dosage of $0.5 \mathrm{mg}$. In all patients, the goal dosage of $3.5 \mathrm{mg}$ per week was accomplished throuout 15-days and preserved till termination of the present work. Cabergoline was distributed for a cycle of 30-days, and the cases had to go back an empty bundle to get a new one. As a protection precaution, researchers can be called by telephone at any instance in situation cases had to told negative events. An echocardiogram has been carried out earlier and throughout following-up.

b- Control group: Cases had been exposed to a wait-and-see method with no medical treatments. All people had been assessed at 6 and 12-mths.

\section{Tumoursize Assessment via MRI:}

MRI images had been done with gadolinium contrast and assessed via qualified neuroradiologists at all institutions. Maximal tumour diameter in every plane had been employed for MRI images comparing. Matching had been done with the latest images, and as well with antecedent existing images. A variation in tumour volume was taken into consideration as large and recorded as if a distinction of at minimum diameter of $0.2 \mathrm{~cm}$ was found.

Casesexperienced pituitary characteristic and neuroophthalmological evaluation involving visible field earlier than and 4-6-wks afterward surgical operation. At every visit, essential symptoms and bodily circumstance had been evaluated, and reassessment of pituitary feature and vision had been done as per standard medical procedure. Pituitary hormone shortages had been managed with hormone substitution treatment, excluding for growing hormone shortage that wasn't repeatedly assessed or managed.

\section{Immuno-histo-chemistry (IHC):}

Immuno-staining for complete pituitary hormones expressing and $\mathrm{Ki}-67$ proliferating index was done in the particular medical pathology labs. D2R and estrogen receptors [ER a (ESR1)] and ERP (ESR2) had been immuno-stained, digitalized, and counted on the Cedars-Sinai Translational Research Core in 53 tumour specimens of DAmanaged cases. The percent of positive cells and staining intensities was recorded for all slides via the immuno-reactivity score system (IRS) [15] and the (QUICK-Score) method [19]

\section{Statistical analysis:}

Data analysis had been performed via windowsbased IBM-SPSS-22 for windows. Data had been tested for normal distributions via the Shapiro Walk testing. Qualitative data had been introduced in the form of frequency and relative percent. Chi square testing $\left(\mathrm{X}^{2}\right)$ and Fisher precise was employed to estimate distinction between qualitative variables as showed. Quantitative data had been introduced 
as mean $\pm \mathrm{SD}$ (Standard deviation) for parametric and medians and ranges for non parametric data. Non-dependent $t$-testing was employed to estimate distinction between quantitative variables. KaplanMeier technique used to estimate event free survival and log rank testing in comparison to survival curves ( $p$-value was taken into consideration to be significant at $\leq 0.05$ level). All statistical evaluations had been tailed with significance Level of $p$-value $\leq 0.05$ shows significant, $p<0>0.05$ shows Nonsignificant change.

\section{Results}

Table (1): Demographic data.

\begin{tabular}{|c|c|c|c|c|c|}
\hline & \multicolumn{2}{|c|}{$\begin{array}{l}\text { Medically-treated } \\
\qquad(n=10)\end{array}$} & \multicolumn{2}{|c|}{$\begin{array}{l}\text { Control } \\
(n=10)\end{array}$} & $p$ \\
\hline $\begin{array}{l}\text { Age }(y r s): \\
\text { Mean } \pm \mathrm{SD}\end{array}$ & \multicolumn{2}{|c|}{$52.98 \pm 3.75$} & \multicolumn{2}{|c|}{$49.34 \pm 4.94$} & .079 \\
\hline $\begin{array}{r}B M I\left(\mathrm{~kg} / \mathrm{m}^{2}\right): \\
\quad \text { Mean } \pm \mathrm{SD}\end{array}$ & \multicolumn{2}{|c|}{$27.42 \pm 3.67$} & \multicolumn{2}{|c|}{$25.64 \pm 4.86$} & .368 \\
\hline $\begin{array}{l}\text { Prolactin }(\mathrm{g} / \mathrm{l}, \\
\text { Mean } \pm \mathrm{SD}\end{array}$ & \multicolumn{2}{|c|}{$25.43 \pm 2.37$} & \multicolumn{2}{|c|}{$26.58 \pm 2.59$} & .894 \\
\hline Sex: & $\mathrm{N}$ & $\%$ & $\mathrm{~N}$ & $\%$ & \\
\hline Male & 7 & 70 & 5 & 50 & .361 \\
\hline Female & 3 & 30 & 5 & 50 & \\
\hline
\end{tabular}

Regrading demographic, no significance found between the groups.

Table (2): Anatomical features of remaining tumour mass.

\begin{tabular}{cccccc}
\hline & $\begin{array}{c}\text { Medically-treated } \\
(\mathrm{n}=10)\end{array}$ & \multicolumn{2}{c}{$\begin{array}{c}\text { Control } \\
(\mathrm{n}=10)\end{array}$} & \\
& $\mathrm{N}$ & $\%$ & $\mathrm{~N}$ & $\%$ & \\
\cline { 2 - 4 } & & & & & \\
\cline { 1 - 2 } Grade: & & & 1 & 10 & .572 \\
I & 3 & 30 & 3 & 30 & \\
II & 1 & 10 & 0 & & \\
III & 6 & 60 & 6 & 60 & \\
IV & & & & & \\
Supra: & 4 & 40 & 4 & 40 & .774 \\
0 & 4 & 40 & 5 & 50 & \\
A & 1 & 10 & 1 & 10 & \\
B & 1 & 10 & 0 & - & \\
C & & & & & \\
Infra: & 4 & 40 & 5 & 50 & .931 \\
0 & 2 & 20 & 1 & 10 & \\
A & 3 & 30 & 3 & 30 & \\
B & 1 & 10 & 1 & 10 & \\
C & & & & & \\
Cavernous: & 5 & 50 & 6 & 60 & .653 \\
0 & 5 & 50 & 4 & 40 & \\
E & & & & & \\
\hline
\end{tabular}

Grade-I, II, III and IV show micro-adenoma, non-invasive macro-adenoma, invasive microadenoma and invasive macro-adenoma, respectively. Stages A, B and C show growing degree of supra-sellar extensions. Stages a, b and c showgrowing degree of infra-sellar extension. Stage $\mathrm{E}$ specifies cavernous sinus invasions. 0 shows absent extra-sellar extension. Non significant was existing among the groups.

\section{Immunostaining pattern results:}

Positive immuno-staining for FSH and $\mathrm{LH}$ was noticed in $60 \%$ of tumours from the controls and in $60 \%$ of tumours in the medically-treated group. There were $20 \%$ and $30 \%$ null tumours in the controls and medically-treated group, respectively. Prolactin staining in a few cells was found in $10 \%$ of tumours from the controls and in none from the medically-treated group. Focal staining for ACTH was found in $10 \%$ of tumours from the controls and in none from the medically-treated group. No association was found among tumour staining features and tumour growing throughout following-up.

Table (3): Remaining tumour mass response.

\begin{tabular}{lcccccc}
\hline & $\begin{array}{c}\text { Medically-treated } \\
(\mathrm{n}=10)\end{array}$ & & \multicolumn{2}{c}{$\begin{array}{c}\text { Control } \\
(\mathrm{n}=10)\end{array}$} & & $p$ \\
\cline { 2 - 3 } & $\mathrm{N}$ & $\%$ & & $\mathrm{~N}$ & $\%$ & \\
\hline Stable & 5 & 50 & & 3 & 30 & $.011^{*}$ \\
Reduction & 4 & 40 & & 0 & & \\
Growing & 1 & 20 & & 7 & 70 & \\
\hline
\end{tabular}

Tumour reduction rate of remaining tumour mass was significantly higher in medically-treated group, while tumour growing rate of remaining tumour mass was significantly higher in control group.

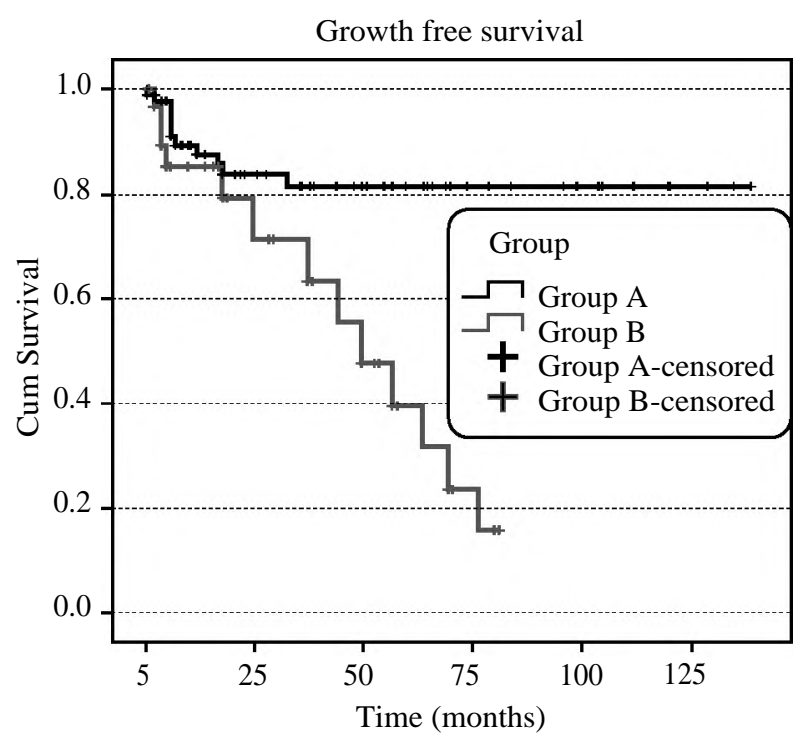

Fig. (1): Tumour growing free survival in cases with postoperative remaining tumour in accordance to therapy group $(p=0.011)$. Tumour growing-free survival at 2 -yrs was $60 \%$, respectively in the controls. Tumour growing-free survival at 2-yrs was $90 \%$ in medically-treated group. 

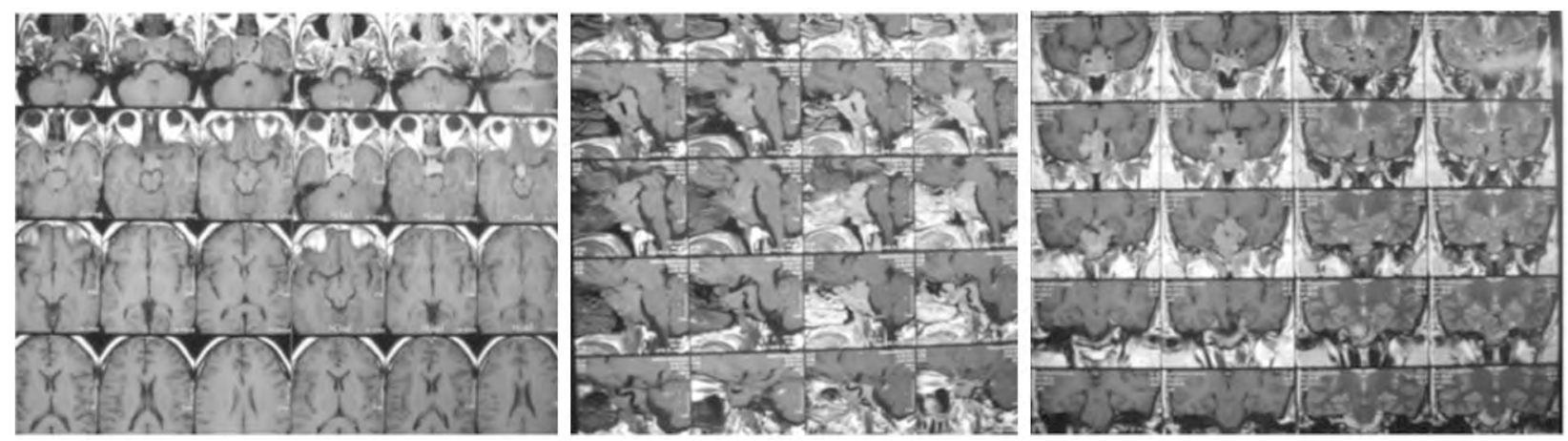

Fig. (2): MRI brain of the same patients after 6 months of DA treatment shows reduction of the residual mass.

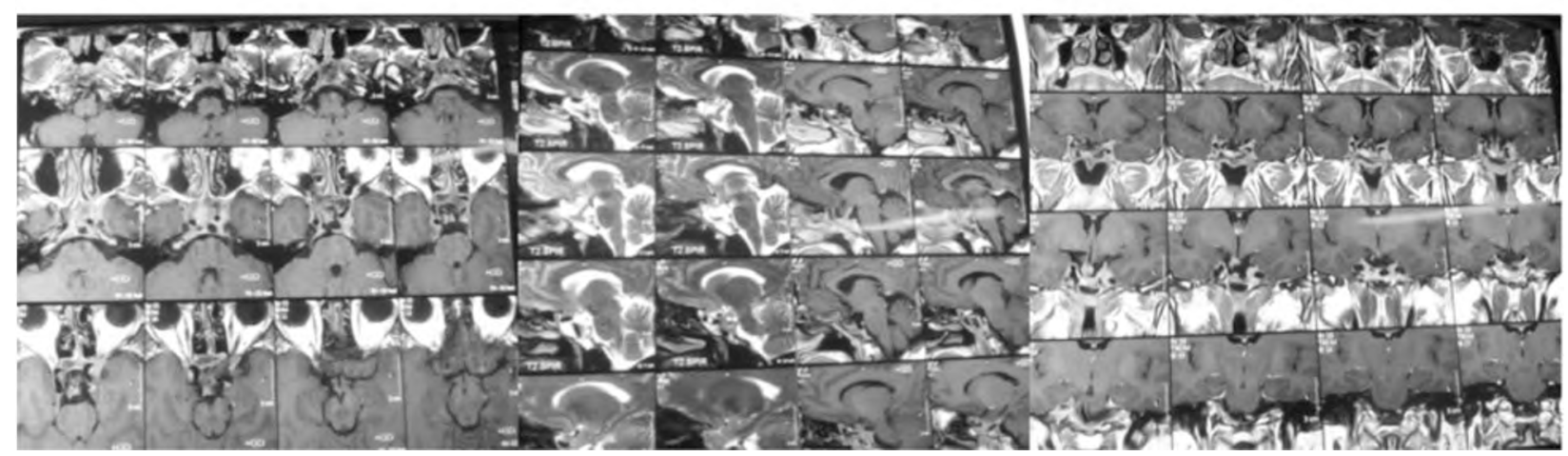

Fig. (3): MRI of the same patients after 2 years medical treatment with complete disappearance of the mass

\section{Discussion}

Clinically NFPAs are the commonest pituitary tumours after ward prolactinomas. The nonattendance of clinical signs and symptoms of hormonal hyper-secretion may make a contribution to the overdue of the disorder diagnosing. Thus, the mainstream of cases are looking for clinical attentions for symptoms due to mass impact, like: Neuroophthalmologic signs and hypo-pituitarism. Other arrangements involve pituitary apoplexy or arelated result on scanning investigations. Mass impact and hypopituitarism cause elevated morbidity and death. But early diagnosing and powerful therapy reduces morbidity and death [17]

Surgical operation is taken into consideration as the primary choice in NFPA managing. But remaining mass is a mutual post-operative result in the majority of these cases because of the reality that the diagnosing is commonly postpended and the tumour reaching a big volume with suprasellarand parasellar extensions [18].

NFPA is a difficult tumour. It is commonly reached to a big volume earlier to its clinical manifestations. Surgical treatment is the primary choice in treating a big NFPA leading to compressing manifestation but with common post-operative remaining masses this is commonly required extra management. Post-operative radio-therapy carried common side results which open the door for postoperative clinical management with dopamine agonist (DA) medications built at the reality that those tumours have a variable amounts of dopamine receptors. Deficiency of randomized, placebocontrolled trials avoids any conclusions on the efficiency of these medications. Its function in controlling post-operative proliferations and reducing the NFPArecurrence rate remains uncertain [19].

The current work aimed to evaluate the efficiency of dopamine agonist medications to reduce or prevent the re-growing of NFPA after ward surgical operation.

This was a prospective, randomized; clinical study that was performed on 20 cases experienced primary trans sphenoidal surgical operation for pituitary adenoma management. Contributors were randomizedand grouped to the medically-treated group (cabergoline) and matching controls (clinical observations).

In the current study, we found that mean \pm SD of age was $52.98 \pm 3.75$ years in medical therapy group, and was $49.34 \pm 4.94$ years in controls, and there were non significant changes among the studied groups regarding ages, BMI, Gender and prolactin levels. 
In agreement with our findings, the study of Mahmoud et al., [19] reported that 32-cases were involved in this work. 21-cases (66\%) were women and 11 -cases $(34 \%)$ were men. Their age ranging between 18 and 65-yrs with age mean of 37-yrs.

Another study of Batista et al., [20] reported that the analyzed subjects had mean \pm SD of age was 49.8 \pm 11.8 -yrs in medical therapy group, and was 50.0 \pm 12.2 -yrs in controls, and non significant changes were found among the studied groups regarding ages and gender, and $56.0 \%$ were females. All cases harbored macro-adenomas earlier tosurgical operation.

Post-surgical surveillance of NFPA is founded on MRI at 3 or $6-m$ ths then afterward 1-yr. When no adenomatous remainder was existing, yearly surveillance is suggested for 5-yrs and then at 7, 10 and 15-yrs. In situation of remainder or unsure MRI, extended yearly surveillance monitor any progressions. Reintervention is specified if fullremainder re-section is possible, or for symptomatic optic path-way compressions, to make a safety borderamid the tumour and the optic path-ways ahead of complementary radio-therapy (RT), or in state of post-RT progressions. In situation of remainder, if the tumour shows raised growing potential, it is frequently suggested to postpone RT until progressions are obvious, as efficiency is analogous if therapy is direct or delayed [21]

In the current study, we found that there was no significance found between the groups as regard anatomical characteristics of remaining tumour mass.

A lot of researches have established that the most dependable prognosticator of tumour regrowing is the existence of remaining tumour after pituitary surgical operation. For instance, Chen et al., [22] concluded a rate of tumourre-growing of $12 \%$ when no remaining tumour was found afterward operation in comparison to arate of $46 \%$ when post-operative remaining tumour was found. Other reports have as well proposed that younger ages, gender, and initial tumour volume canas well be contributive issues [21]

The neuro-surgical method to the sella has altered considerably in the past 10 to 15 -yrs, with the wider spread usage of endoscopic methods. These have allowed for straight visualizations of tumour and ordinary pituitary tissues. Severalauthors have supported that the endoscopic methodeases more wide spread tumour elimination, while not every surgeon agreethatidea [23] .
In the study on our hands, Positive immunostaining for FSH and LH was founded in $60 \%$ of tumours from the controls and in $60 \%$ of tumours in the medically-treated group. There were $20 \%$ and $30 \%$ null tumours in the controls and medicallytreated groups, respectively. Prolactin staining in a few cells was found in $10 \%$ of tumours from the controls and in none from the medically-treated group. Focal staining for ACTH was found in 10\% of tumours from the controls and in none from the medically-treated group. There was no associationamong tumour staining features and tumour growing throughout following-up.

In comparison with the study of Batista et al., [20] which reported that the mean Ki-67 labeling index was 0.8 (0.2 to 1.2$)$. In all, 71 of $80(88.7 \%)$ cases expressed D2R with predominantly cytoplasmic staining and an H-scoring median of 188.0 (120.0 to 300.0), and 18 of 80 (22.5\%) patientsshowed nuclei stained positively for ER with a median H-scoring of 0.0 (0.0 to 10.0). Nonsignificant change was found in IHC tumour phenotypes among the studied groups.

Subsequently the identification of dopaminergic receptor in NFPA, pharma-cological management of NFPA was taken into consideration as asubstitute to radio-therapy or surgical operation. Up to now, the medicalusage of DAs in NFPA caseswasassessed in some reports.16-18 But, the majority of them current modest and inconclusive findings, and no medical treatment for NFPA was confirmedto date $(24 ; 25)$.

In the current work, we found that tumour reduction rate of remaining tumour mass was significantly higher in medically-treated group, while tumour growing rate of remaining tumour mass was significantly higher in control group.

Batista et al., [20] concluded that tumour shrinkage can characteristically be found in the 1 st-yr of cabergoline use ( $p$-value $=0.02)$, taking in to consideration that they found a very small number instances of overdue tumour shrinkage in their-report. Similarly, considerable shrinkage in NFPA with quick intervals $(6 \mathrm{mo})$ of cabergoline was formerly defined in small report of Vieira et al., [25]. Altogether, those data suggest that a minimal duration of 6-mths may be employed for the estimation of responding to cabergoline for NFPA management assessment. But, the duration for cabergoline usage in remaining tumour hasn't been expected yet, and medical research with extended following-up may be helpful to find it. 
The most suitable medical report up to now assessing DA in NFPA management was lately published by Greenman et al., [26], In that report, 55 -cases with a remaining tumour (preventive group) and 24 cases with remaining tumour growing (remedial group) have been managed with cabergoline and in comparison, with controls of 60 NFPA cases. 19 Substantial tumour shrinkage and an enhanced progressing free survival have been located in the groups with DA usage. But, this report was not a clinical trial and had some essential restrictions, like no standardizations of DA medication and doses.

Also, Garcia et al., [27] was carried out on 19cases (10 males and 9 females) followed on the University Hospital of Brasilia and harboring nonfunctioning pituitary macro-adenomas have been registered in the investigation. 11 cases have been formerly presented to trans-sphenoidal surgical operation, and in 8 cases no previous treatments were founded. Their responding to the usage of cabergoline $(2 \mathrm{mg} / \mathrm{wk})$ for 6 - $\mathrm{mths}$ was assessed. Substantial tumour reduction (above $25 \%$ from base-line tumour size) was found in $6(31.6 \%)$ of the 19 cases, and no negative results have been found throughout management. In 9 cases $(47.4 \%)$, a decrease in tumour size of a minimum $10 \%$ was noticed; while tumour growing was found in 4 cases (rise above $25 \%$ was only found in a single case). Cabergoline ( $2 \mathrm{mg} / \mathrm{wk}$ ) may cause considerable tumour reduction in NFPA in a significant variety of cases, and this impact may be found early (6-mths after ward initial medications). Thus, this treatment approach can be a lower cost and secure opportunity for treatment of NFPA in cases with remnant or recurrent tumour after ward transsphenoidal surgical operation or in those not operated via contraindication or rejection to operative procedures.

In contrast, Dekkers et al., [28] said that unprompted decrease of tumour volume happened in $29 \%$ in their cases and therefore they recommend that just observations of some chosen patients of NFPA can be a choice for management supplied there are no compressive symptoms as visible influence or hypo-pituitarism.

Furthermore, in the current work, we determined that tumour growing free survival in cases with post-operative remaining tumour in accordance to treatment group $(p=0.011)$. Tumour growing-free survival at 2-yrs was $60 \%$, correspondingly in the controls. Tumour growing-free survival at 2 -yrs was $90 \%$ in medically-treated group.
Our findings are in agreement with Batista et al., [20] said that the mean progressions-free survive was 23.2-mths [95\% confidence range (CI), 22.324.1 ] in the medically-treated group, which was considerably elevated than the 20.8 -mths $(95 \% \mathrm{CI}$, 19.2-22.4) of the controls ( $p=0.01$; Fig. 3B). The real 6-mths progressions-free survival was $96 \%$ and $94 \%$ for cases from the medically-treated and controls, correspondingly. The real 1-yr progressions-free survival for cases in the medicallytreated group was $94 \%$, in comparison with $78 \%$ in the controls.

In conclusion, cabergoline is a secure and powerful medication and appears to be a hopeful substituent to radio-therapy for the treatment of NFPA cases with remaining tumour. But, there's no dependable clinical, laboratory, or immunohistochemical marker to expect their responsiveness to cabergoline.

\section{References}

1- ROGERS A., KARAVITAKI N. and WASS J.A.: Diagnosis and management of prolactinomas and nonfunctioning pituitary adenomas. BMJ, 349: g5390, 2014.

2- GREENMAN Y. and STERN N.: Optimal management of non-functioning pituitary adenomas. Endocrine, 50: 51-55, 2015.

3- CASTINETTI F., DUFOUR H., GAILLARD S., JOUANNEAU E., VASILJEVIC A., VILLA C., et al.: Nonfunctioning pituitary adenoma: when and how to operate? What pathologic criteria for typing? Ann. Endocrinol. (Paris), 76: 220-227, 2015.

4- MINNITI G., CLARKE E., SCARINGI C. and ENRICI R.M.: Stereotactic radio-therapy and radiosurgical operation for non-functioning and secreting pituitary adenomas. Rep. Pract Oncol. Radiother., 21: 370-378, 2016.

5- KIM M.Y., KIM J.H., OH Y.K. and KIM E.: Long-term outcomes of surgical operation and radio-therapy for secreting and non-secreting pituitary adenoma. Radiat Oncol. J., 34: 121-127, 2016.

6- AYUK J. and STEWART P.M.: Mortality following pituitary radio-therapy. Pituitary, 12: 35-39, 2009.

7- OLSSON D.S., NILSSON A.G., BRYNGELSSON I.L., TRIMPOU P., JOHANNSSON G. and ANDERSSON E.: Excess mortality in women and young adults with nonfunctioning pituitary adenoma: A Swedish Nationwide Study. J. Clin. Endocrinol. Metab., 100: 2651-2658, 2015.

8- GIUSTINA A., CHANSON P., KLEINBERG D., BRONSTEIN M.D., CLEMMONS D.R., KLIBANSKI A., et al.: Expert consensus document: A consensus on the medical treatment of acromegaly. Nature Reviews Endocrinology, 10 (4): 243-8, 2014.

9- GABALEC F., BERANEK M., NETUKA D., MASOPUST V., NAHLOVSKY J., CESAK T., et al.: Dopamine 2 receptor expression in various pathological types of clinically non-functioning pituitary adenomas. Pituitary, 15 (2): 222-6, 2012. 
10- COLAO A., Di SOMMA C., PIVONELLO R., FAGGIANO A., LOMBARDI G., et al. Medical therapy for clinically non-functioning pituitary adenomas. Endocrinerelated cancer, 15 (4): 905-15, 2008.

11- GARCIA E.C., NAVES L.A., SILVA A.O., de CASTRO L.F., CASULARI L.A., et al.: Short-term treatment with cabergoline can lead to tumour shrinkage in patients with nonfunctioning pituitary adenomas. Pituitary, 16 (2): 18994, 2013.

12- VIEIRA NETO L., WILDEMBERG L.E., MORAES A.B., COLLI L.M., KASUKI L., et al.: Dopamine receptor subtype 2 expression profile in nonfunctioning pituitary adenomas and in vivo response to cabergoline therapy. Clinical Endocrinology, 82 (5): 739-46, 2015.

13- ROBENSHTOK E., BENBASSAT C.A., HIRSCH D., TZVETOV G., COHEN Z.R., IRAQI H.M., et al.: Clinical course and outcome of nonfunctioning pituitary adenomas in the elderly compared with younger age groups. Endocrine Practice, 20 (2): 159-64, 2014.

14-GREENMAN Y., COOPER O., YAISH I., ROBENSHTOK E., SAGIV N., JONAS-KIMCHI T., et al.: Treatment of clinically nonfunctioning pituitary adenomas with dopamine agonists. Eur. J. Endocrinol., 175 (1): 63-72, 2016.

15- GATTO F., FEELDERS R.A., VAN DER PAS R., KROS J.M., WAAIJERS M., SPRIJ-MOOIJ D., et al.: Immunoreactivity score using an anti-sst2A receptor monoclonal antibody strongly predicts the biochemical response to adjuvant treatment with somatostatin analogs in acromegaly. The Journal of Clinical Endocrinology \& Metabolism, 98 (1): E66-71, 2013.

16- LEAKE R., BARNES D., PINDER S., ELLIS I., ANDERSON L., ANDERSON T., et al.: Immunohistochemical detection of steroid receptors in breast cancer: A working protocol. Journal of Clinical Pathology, 53 (8): 634-5, 2000.

17- VIEIRA NETO, LEONARDO, BOGUSZEWSKI, CESAR L., ARAÚJO, LUIZ ANTÔNIO de, BRONSTEIN, MARCELLO D., MIRANDA, PAULO AUGUSTO C., MUSOLINO, NINA R. de C., NAVES, LUCIANA A., VILAR, LUCIO, RIBEIRO-OLIVEIRA JÚNIOR, ANTÔNIO and GADELHA, MÔNICA R.: A review on the diagnosis and treatment of patients with clinically nonfunctioning pituitary adenoma by the Neuroendocrinology Department of the Brazilian Society of Endocrinology and Metabolism. Archives of Endocrinology and Metabolism, 60 (4): 374390. https://doi.org/10.1590/2359-3997000000179, 2016

18- COLAO A., DI SOMMA C., PIVONELLO R., FAGGIANO A., LOMBARDI G. and SAVASTANO M.: DOI: 10.4236/ojmn.2020.102029 274 Open Journal of Modern Neurosurgical operation S. Medical Therapy for Clinically Non-Functioning Pituitary Adenomas. Endocrine-Related
Cancer, 15, 905-915. https://doi.org/10.1677/ERC-08 0181, 2008.

19- MAHMOUD M., MOUSSA A.A., ABOKRESHA A.E. and YOUSEF H.A.: Post-operative Use of Dopamine Agonist in Controlling the Remaining Mass in Non Functioning Pituitary Adenoma. Open Journal of Modern Neurosurgical operation, 10, 267-274. https://doi.org/ 10.4236/ojmn.2020.102029, 2020 .

20- BATISTA R.L., MUSOLINO, NINA R.C., CESCATO, VALTER A.S., DA SILVA, GILBERTO O., MEDEIROS, RAPHAEL S.S., HERKENHOFF CLARISSA G.B., TRARBACH ERICKA B. and CUNHA-NETO MALEBRANCHE B.: Cabergoline in the Management of Remaining Nonfunctioning Pituitary Adenoma. American Journal of Clinical Oncology, 42 (2): 221-227. doi:10.1097/coc.0000000000000505, 2019.

21- CORTET-RUDELLIA R., JEAN-FRANÇOIS BONNEVILLEB, FRANCOISE BORSON-CHAZOTC, LORRAINE CLAVIERD and BERNARD COCHE: Postsurgical management of non-functioning pituitary adenoma, Annalesd'Endocrinologie, Volume 76, Issue 3, July, Pages 228-238, 2015.

22- CHEN Y., WANG C.D., SU Z.P., CHEN Y.X., CAI L., ZHUGE Q.C. and WU Z.B.: Natural history of postoperative nonfunctioning pituitary adenomas: A systematic review and meta-analysis. Neuroendocrinology, 96 (4): 333-342, 2012

23- MORTINI P. CONS: Endoscopic endonasal transsphenoidal pituitary surgical operation is not superior to microscopic transsphenoidal surgical operation for pituitary adenomas. Endocrine, 47 (2): 415-420, 2014.

24- GABALEC F., DRASTIKOVA M., CESAK T., et al.: Dopamine 2 and somatostatin 1-5 receptors coexpression in clinically nonfunctioning pituitary adenomas. Physiol. Res., 64: 369-377, 2015.

25- VIEIRA NETO L., WILDEMBERG L.E., MORAES A.B., et al.: Dopamine receptor subtype 2 expression profile in nonfunctioning pituitary adenomas and in vivo response to cabergoline therapy. Clin. Endocrinol. (Oxf), 82: 739746, 2015

26- GREENMAN Y., COOPER O, YAISH I., et al.: Treatment of clinically nonfunctioning pituitary adenomas with dopamine agonists. Eur. J. Endocrinol., 175: 63-72, 2016.

27- GARCIA E.C., NAVES L.A., SILVA A.O., et al.: Shortterm treatment with cabergoline can lead to tumour shrinkage in patients with nonfunctioning pituitary adenomas. Pituitary, 16: 189-194, 2013.

28- DEKKERS O.M., HAMMER S., de KEIZER R.J., ROELFSEMA F., SCHUTTE P.J., SMIT J.W., ROMIJN J.A and PEREIRA A.M.: The Natural Course of NonFunctioning Pituitary Macroadenomas. European Journal of Endocrinology, 156, 217-224. https://doi.org/10.1530/ eje.1.02334, 2007. 


\section{تقييم استخدام محفزات الدوبامين

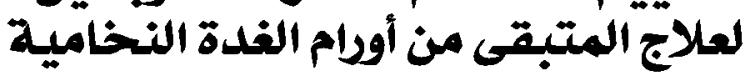 \\ الفيرنشطة بعل إجمن أجراء الجرة الجراحة}

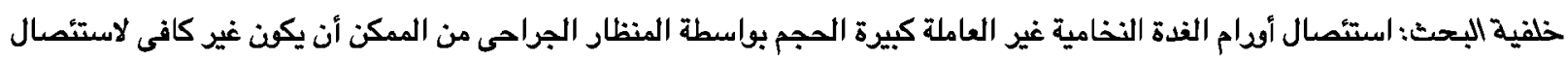

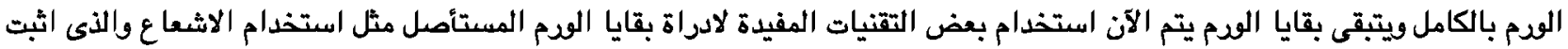
فاعلية بنسبة تصل إلى ـ 9٪ إلا أن وجد له مضاعفات كصدوث جلطات وكصدوث كسل للفدة النخامية. مما فتح المجال إلى دراسة تأثير منشطات الدوبامين وتأثيرها على بقايا الورم الحميد النخامى غير النشط. الهدف من البحث: تقيم هذه الدراسة سلامة ودقة استخدام محفزات الدوبامين فى ادارة الودم الحميد النخامى المتبقى غير النشط بعد إجراء الجراحة.

المرضى وطريقة البحث: أجريت الجراحة على (. Fريض) تم التخالهم إلى المستشفى لاجراء عمليات لاستئصال أودام الغدة النخامية

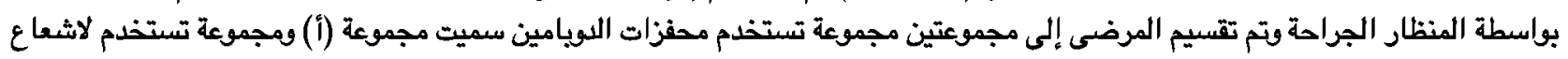
وسميت مجموعة (ب). نتائج البحث: أظهرت النتائج مجموعة (أ) تم استقرار بنسبة (. \%) وتم تقلص بقايا المرم الحميد النخامى بنسبة (.ع٪) وتم ارتجاع الوم بنسبة (1).

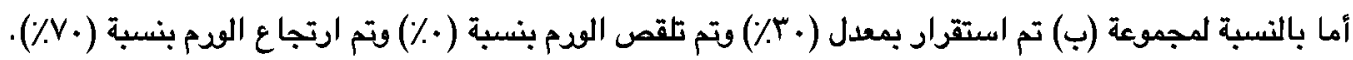
الاستتاج: استخدام محفزات الوبامين بعد الجراحة فى ادارة الورم الحميد النخامى المتبقى غير النشط أكثر فاعلية وأماناً للمريض مقارنة باستخدام الاشعاع وماله من اضرار جانبيه على المريض. 